\title{
EFFECTS OF CORTICOSTEROIDS IN VERY LOW BIRTH WEIGHT NEWBORNS DEPENDENT ON MECHANICAL VENTILATION
}

\author{
Marta M. G. B. Mataloun, Cléa R. Leone, Maria Augusta C. Gibelli, and \\ Flávio A. C.Vaz
}

MATALOUN MMGB et al. Effects of corticosteroids in very low birth weight newborns dependent on mechanical ventilation. CLINICS 60(2):113-120, 2005.

Corticosteroids have been used in bronchopulmonary dysplasia prevention because of their antiinflammatory effects. Among their effects is a decrease in the incidence of bronchopulmonary dysplasia. However, short- and long-term side effects have been detected in preterm newborns.

PURPOSE: To analyze the effects of corticosteroids on bronchopulmonary dysplasia, length of stay, mortality, growth, as well as the adverse effects in very low birth weight newborns between 10 and 14 days of life and dependent on mechanical ventilation.

METHODS: Cohort study. All newborns with a birth weight under $1500 \mathrm{~g}$, mechanical ventilation-dependent between 10 and 14 days of life, during the period January 2000 and June 2001 were included $(\mathrm{n}=38)$. They were divided into 2 groups: Group I with corticosteroids $(n=16)$ and Group II without corticosteroids $(\mathrm{n}=22)$. Dexamethasone administration: from the $10^{\text {th }}$ day of life, $\mathrm{d}_{1}-\mathrm{d}_{3}, 0.3 \mathrm{mg} / \mathrm{kg} / \mathrm{d} ; \mathrm{d}_{4}-\mathrm{d}_{6}, 0.2 \mathrm{mg} / \mathrm{kg} / \mathrm{d} ; \mathrm{d}_{7}-\mathrm{d}_{9}, 0.1 \mathrm{mg} / \mathrm{kg} / \mathrm{d}$. Respiratory evolution, bronchopulmonary dysplasia (oxygen dependence at 28 days of life), growth pattern and the presence of adverse effects were analyzed.

RESULTS: The incidence of bronchopulmonary dysplasia was 6.5\% (Group I) and 30\% (Group II), $P=.07$. A decrease in growth was detected in Group I compared with Group II (change in weight: Group I — $47 \mathrm{~g} /$ week, Group II — $85.5 \mathrm{~g} /$ week, $P=.06$; change in head circumference: Group I $-0.75 \mathrm{~cm} /$ week, Group II $-1 \mathrm{~cm} /$ week, $P=.05$ ).

CONCLUSION: Use of corticosteroids in very low birth weight infants dependent on mechanical ventilation during the first 10 to 14 days of life did not affect the respiratory evolution and occurrence of bronchopulmonary dysplasia, but the velocity of growth was reduced.

KEYWORDS: Corticosteroids. Very low birth weight newborn. Bronchopulmonary dysplasia.

The use of surfactants and the introduction of new respiratory therapeutic modalities has changed the outcome for preterm newborns with respiratory distress syndrome, even though effects on the incidence of bronchopulmonary dysplasia (BPD) have not been observed.

Bronchopulmonary dysplasia is one of the main causes of morbidity in the neonatal intensive care unit (NICU), especially for very low birth weight infants, with reported

From the Child's Institute, Nursery Annexed to the Maternity, Hospital das Clínicas, Faculty of Medicine, University of São Paulo - São Paulo/SP, Brazil. E-mail: mataloun@uol.com.br

Received for publication on October 22, 2004.

Accepted for publication on October 26, 2005. incidences of up to $71 \%$ among the newborns with a gestational age of 25 weeks, ${ }^{1} 30 \%$ among newborns with a birth weight under $1500 \mathrm{~g},{ }^{2}$ and up to $100 \%$ for birth weights between 500 and 750 g. 1,3,4

A greater survival of very low birth weight infants with BPD results in higher costs, especially in for the NICU, in addition to longer hospital stays and, after the discharge, frequent re-hospitalizations.

Several clinical trials have described favorable effects with the use of corticosteroids in the neonatal period, including a reduction of the incidence of BPD, ${ }^{5-9}$ the duration of mechanical ventilation, ${ }^{6,10-13}$ and short-term improvement in pulmonary compliance..$^{10,11}$ 
However, concomitant with favorable effects of corticosteroids in preterm infants who are dependent on mechanical ventilation, several adverse effects have also been described such as hyperglycemia, ${ }^{6,13-15}$ systemic arterial hypertension, ${ }^{10,13-16}$ interventricular septum hypertrophy, ${ }^{5,15,17}$ irritability, ${ }^{5}$ gastrointestinal perforation, ${ }^{18}$ intensification of prematurity retinopathy,$^{19}$ suppression of the adrenal axis, ${ }^{20}$ alteration in mineral homeostasis ${ }^{21}$ and the bone growth, ${ }^{22}$ postnatal growth retardation, ${ }^{23,24}$ and an increase of infection incidence..$^{25}$

In addition to these short-term adverse effects, a higher incidence of cerebral palsy and neurological alterations have been observed in preterm newborns that received corticosteroids in the neonatal period and underwent longterm evaluation. ${ }^{26,27}$

This study analyzed the effects of the use of dexamethasone beginning between 10 and 14 days of life in very low birth weight infants and dependent on mechanical ventilation. We analyzed the incidence of BPD and its evolution, the duration of mechanical ventilation and oxygen therapy, the adverse effects and mortality with the purpose of evaluating the hypothesis that this corticosteroid can benefit the respiratory evolution of these newborns even though its use also has some adverse effects.

\section{METHODS}

A cohort study was performed that included 38 preterm newborns. These were selected according the the following inclusion criteria: gestational age $<37$ weeks, birth weight $<1500 \mathrm{~g}$, dependence on mechanical ventilation between the $10^{\text {th }}$ and $14^{\text {th }}$ days of life.

Newborns with congenital malformations and chromosomal alterations were excluded, as were newborns who presented one of the following diagnoses at the beginning of the study: infection, hyperglycemia, systemic arterial hypertension, or hemorrhagic syndromes.

Newborns selected for the study were divided into 2 groups: Group I - received dexamethasone and Group II — did not receive dexamethasone.

Dexamethasone was administered to newborns that fulfilled the inclusion criteria according to the following therapeutic schedule beginning on the $10^{\text {th }}$ day of life: every 12 hours, for 9 days as follows: day 1 through $3-0.3 \mathrm{mg} / \mathrm{kg} /$ day; day 4 through $6-0.2 \mathrm{mg} / \mathrm{kg} / \mathrm{d}$; and day 7 through 9 $-0.1 \mathrm{mg} / \mathrm{kg} / \mathrm{d}$.

Gestational age was determined from the date of the last menstruation; this was confirmed by the New Ballard method. ${ }^{28}$ When a difference of 2 or more weeks in estimated gestational age occurred between the clinical evaluation through this method and the one determined by the date of last menstruation, the clinical evaluation was used. The newborns were classified as adequate for gestational age (AGA), when their birth weights were below percentile 90 and above percentile 10 of the Ramos Intrauterine Growth Curve, ${ }^{29}$ and small for gestational age when their birth weights were below percentile 10 of that curve. ${ }^{30}$

The development of BPD was analyzed as the factor of primary concern. As a secondary concern, the following were observed: duration of mechanical ventilation and oxygen therapy, mortality, length of stay in the neonatal unit, neonatal growth pattern during the hospital stay, and the occurrence of adverse effects including systemic infection, fungal infection, hyperglycemia, systemic arterial hypertension, persistence of ductus arteriosus, necrotizing enterocolitis, intracranial hemorrhage, retinopathy of prematurity, and metabolic bone disease.

We defined BPD as dependence on oxygen in preterm newborns at risk at 28 days of life confirmed by clinical and radiological alterations..$^{31,32}$

Diagnosis of pneumonia was established in the presence of clinical deterioration, tachypnea, rales, and radiological signs of condensation and/or positive blood culture. Infection was defined as the occurrence of clinical worsening, poor peripheral perfusion, hypoactivity, and positive blood culture. Hyperglycemia was defined as a plasma glycemic level equal to or higher than $150 \mathrm{mg} / \mathrm{dL} .{ }^{33}$ Systemic arterial hypertension was defined as a systolic pressure equal to or higher than 2 standard deviations from that reference. ${ }^{34}$ The diagnosis of persistence of ductus arteriosus was based on the presence of clinical manifestations such as systolic or continuous murmur in the second left intercostal space, pulsatile precordium or visible ictus, or wide pulses at the physical examination and confirmed by the echocardiogram. The diagnosis of necrotizing enterocolitis was made when the following clinical alterations were noted: abdominal distention, bloody stools, pain at abdominal palpation and/ or radiological alterations, distended intestinal loops, edema in the walls of intestinal loops, and the presence of pneumatosis intestinalis. ${ }^{35}$ Diagnosis of intracranial hemorrhage was based on the result of the head ultrasonography as classified according to Papile. ${ }^{36}$ Perinatal asphyxia was diagnosed when the newborn presented an Apgar score $<6$ at the fifth minute of life. ${ }^{37}$

A chest $\mathrm{x}$-ray was performed at admission at any time when clinically indicated, and at 28 days of life; head ultrasonography was performed in the first 7 days of life and at approximately 14 and 30 days of life; an echocardiogram was performed in the presence of a murmur in the second left intercostal space or wide pulses with visible ictus were detected; an ophthalmologic examination was performed at 4 weeks of life by a pediatric ophthalmologist using the 
international classification. ${ }^{38}$ The assistance to the newborn followed the guidelines in the NICU and was prescribed by the responsible assistant doctor, who was blinded to the study groups.

For the purposes of statistical analysis, a database was developed using the EPI-INFO 6.04 software. For continuous variable analysis, the $t$ test and Mann-Whitney test were used, and for discrete variables, the chi square test was used. Statistical significance was declared when $P<.05$.

\section{RESULTS}

Among 38 very low birth weight newborn infants admitted between January 2000 and July 2001 were included, 16 were selected for Group I (dexamethasone treated) and 22 for Group II.

The groups did not differ regarding gestational age, birth weight, gender, color, size for gestational age, perinatal asphyxia, and surfactant administration (Table 1).

Table 1 - Characteristics and evolution of the studied population.

\begin{tabular}{llll}
\hline & Group I & Group II & $P$ \\
\hline Gestational age (wk) & $28.9 \pm 1.8$ & $29 \pm 1.7$ & .99 \\
Birth weight (g) & $1082.18 \pm 200$ & $970 \pm 264$ & .29 \\
Gender (M/F) (\%) & $43.75 / 56.25$ & $50 / 50$ & .95 \\
Color (white/nonwhite) & $62.5 / 37.5$ & $68.2 / 32.8$ & .98 \\
Adequate for gestational & 68.7 & 59.0 & .78 \\
age (\%) & & & \\
Small for gestational age (\%) & 31.2 & 41.0 & .78 \\
Perinatal asphyxia (\%) & 66.6 & 35.0 & .15 \\
Surfactant (\%) & 93.75 & 68.2 & .13 \\
Hospital stay (d) & $78.6 \pm 40.2$ & $64.8 \pm 26.0$ & .32 \\
$\begin{array}{l}\text { Duration of oxygen } \\
\text { therapy (d) }\end{array}$ & $20.1 \pm 2.0$ & $8.0 \pm 8.2$ & .05 \\
$\begin{array}{l}\text { Extubation (d) } \\
\text { Duration of mechanical }\end{array}$ & $19.1 \pm 5.0$ & $12.9 \pm 10.0$ & .09 \\
ventilation (d) & & & \\
\hline
\end{tabular}

A tendency for a higher incidence of BPD occurred in Group I (Group I - 62.5\%, Group II $-22.7 \%, P=.07$ ). No effect of the use of dexamethasone on duration of mechanical ventilation was observed (Group I - $19 \pm 14$ days, Group II $-12.9 \pm 10$ days, $P=.09)$. However, Group II used oxygen for a shorter period (Group I $-20 \pm 10$ days, Group II $-8 \pm 4$ days, $P=.05)$.

There was a tendency for reduced mortality in the group that received dexamethasone (Group I - 6.5\%, Group II - 30\%, $P=.07)$. Nevertheless, an influence by the use of dexamethasone on the hospitalization length was not observed (Group I $-78.5 \pm 40$ days, Group II $-64.8 \pm 26$ days, $P=.32$ ) (Table 2).

A reduced weight gain and growth velocity of the head
Table 2 - Adverse effects in the studied groups (\%).

\begin{tabular}{llll}
\hline & Group I & Group II & $P$ \\
\hline Pneumonia & 62.5 & 63.6 & .95 \\
Bacterial infection & 93.0 & 77.2 & .60 \\
Fungal infection & 0 & 4.5 & .90 \\
Persistence of ductus arteriosus & 50.0 & 54.5 & .95 \\
Interstitial emphysema & 25.0 & 22.0 & .99 \\
Necrotizing enterocolitis & 6.2 & 18.1 & .37 \\
Hyperglycemia & 6.2 & 0.0 & .43 \\
Blood hypertension & 0.0 & 4.5 & .99 \\
Gastrointestinal bleeding & 0.0 & 4.5 & .99 \\
Intracranial hemorrhage & 31.2 & 9.6 & .10 \\
Phosphorous deficiency & 37.5 & 13.6 & .12 \\
\hline
\end{tabular}

circumference was detected between 28 and 36 weeks of corrected gestational age in Group I compared with Group II (change in weight: Group I - $47 \mathrm{~g} /$ week and Group II - $85.5 \mathrm{~g} /$ week, $P=.06)$; change in head circumference: Group I $-0.75 \mathrm{~cm} /$ week and Group II $-1 \mathrm{~cm} /$ week, $P=$ .05) (Figure 2). Regarding length, there were no observed differences between the groups (Figure 2).

Weight gain (Figure 1) and growth velocity of the head circumference (Figure 2) between 28 and 36 weeks of corrected gestational age were reduced in Group 1 as compared to Group 2: weight gain was $47 \mathrm{~g} /$ week in Group I, $85.5 \mathrm{~g} /$ week in Group II, $(P=.06)$; the head circumference increased by $0.75 \mathrm{~cm} /$ week in Group I, vs. $1.00 \mathrm{~cm} /$ week in Group II $(P=.05)$

\section{DISCUSSION}

Corticosteroids have been used with the aim of reducing the inflammatory responses due to antiinflammatory reactions $^{39,40}$ triggered by several factors, such as hyperoxia, ${ }^{41}$ infection, ${ }^{42}$ and mechanical ventilation ${ }^{43,44}$ among others, upon the developing lung. These inflammatory responses may contribute to reduced alveolarization, ${ }^{41-44}$ which constitutes one of the main characteristics of BPD. ${ }^{45}$

Favorable effects on the incidence BPD as a result of the use of corticosteroids in preterm newborns dependent on mechanical ventilation at 10 to 14 days of life were not observed in this study. Neither did a reduction of the duration of ventilation, nor of the hospital stay result from the use of corticosteroids, in contrast to what has been observed by others. ${ }^{7,9,10,12,13}$ However, we found a tendency for reduced mortality among newborns that received corticosteroids as described. ${ }^{7,9,10,12,13}$ It is possible that because of the design of the study, in which the inclusion criterion was children dependent on mechanical ventilation between 10 and 14 days of life, newborns with severe pulmonary diseases may have been selected for inclusion, and consequently, evidence of favorable effects of 


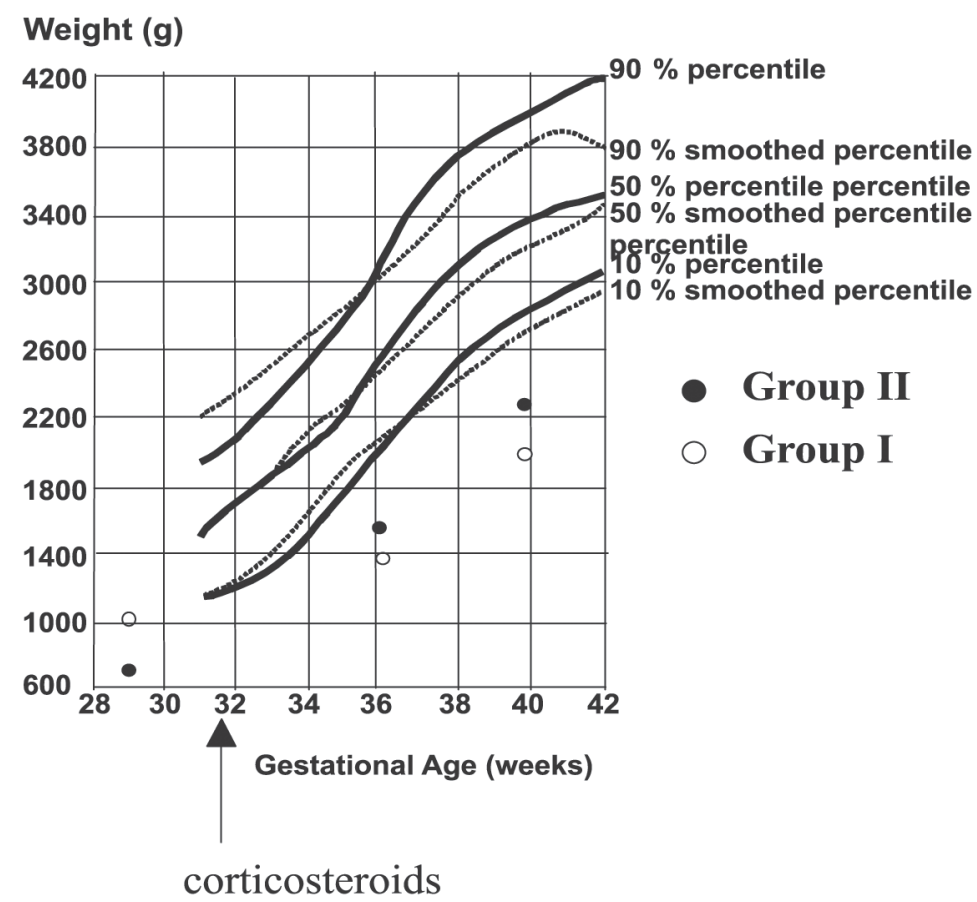

Figure 1 - Evolution of weight of included patients between 36 and 40 weeks of corrected gestational age in children treated with corticosteroids (Group I - open circles, treatment started at week 32), or untreated (Group II - closed circles). Observed values are compared to the 10, 50, and 90 percentile curves (percentile curves: full lines; smoothed percentile curves: dotted lines).

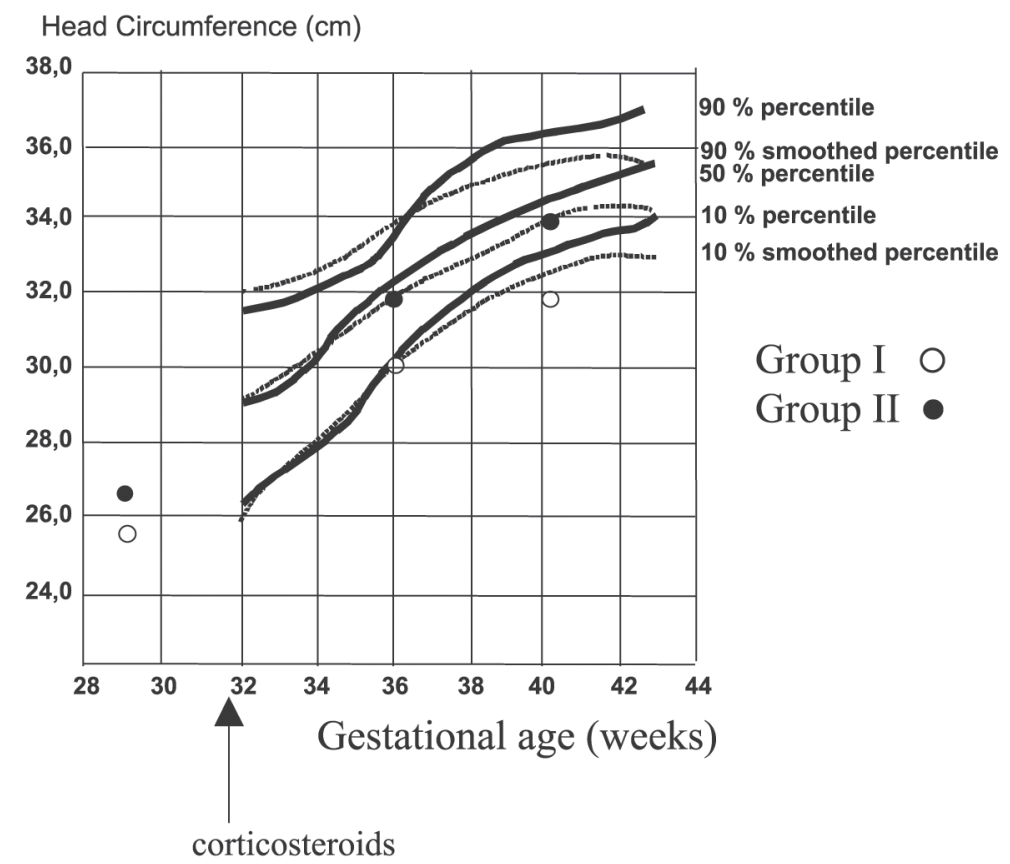

Figure 2 - Evolution of head circumference of included patients between 36 and 40 weeks of corrected gestational age in children treated with corticosteroids (Group I - open circles, treatment started at week 32), or untreated (Group II - closed circles). Observed values are compared to the 10,50, and 90 percentile curves (percentile curves: full lines; smoothed percentile curves: dotted lines).

corticosteroids upon the respiratory function in this selected group may not have become evident. However, it is important to note that the newborns included in the treated group had a tendency for a lower mortality rate, which indirectly could be suggesting that despite the severity of their con- ditions, certain benefits may have occurred.

Over the past decades, methods have differed as to the beginning of administration of corticosteroids: (i) from the first hours of life (early), ${ }^{6,7-9,16,45-47}$ (ii) from 7 to 14 days of life (moderately early), ${ }^{12,23,48}$ (iii) after 14 days of life 
(late) ${ }^{10,13,49,50}$. Doses and the length of treatment (from 9 to 42 days) are also reported.

Despite this great variability in the method of administration of corticosteroids, favorable effects have commonly been detected. A reduction in the incidence of BPD due to the therapeutic schedules that started either in the first hours of life or between the $7^{\text {th }}$ and $14^{\text {th }}$ day of life $\mathrm{e}^{7,9,48,51}$ have been reported, in addition to a reduction in the duration of mechanical ventilation and great success with extubation in all schedules. ${ }^{7,9,48,51,52}$

Nevertheless, common adverse effects have also been described in the short-term, such as hyperglycemia, ${ }^{6,9,13,14,15,48,51}$ systemic arterial hypertension, ${ }^{9,10,13-16,51,52}$ hypertrophy of the myocardium, ${ }^{5,15,17,51}$ gastrointestinal bleeding, ${ }^{9,51}$ and an elevation in the incidence of infections. ${ }^{25,51,52}$

In this study the use of corticosteroids did not alter most of the factors described above. However, an increase in the incidence of hyperglycemia occurred that was similar to that found in other studies. In addition, we observed a decrease in the growth between 28 and 36 weeks of corrected gestational age. Others have described this influence in the postnatal growth. Papile et al. ${ }^{23}$ detected a reduction in the head circumference growth of newborns during corticosteroid therapy.

Mataloun et al. ${ }^{24}$ observed a decrease in growth during corticosteroid therapy in a study that used higher doses over a prolonged period; growth resumed after the suspension of treatment.

At present, long-term follow-ups of children who received corticosteroids during the neonatal period have been revealing neurological alterations and an increase of the incidence of cerebral palsy. ${ }^{9,52}$ It is important to emphasize that these long-term neurological alterations were found in children who received corticosteroids in the first 96 hours of life and after 14 days. Additionally, these studies are heterogeneous regarding the dosage and length of therapeutic schedule used. The studies that detected increased incidence of cerebral palsy were of children who received therapeutic schedules of longer duration. However, Shinwell et al. ${ }^{53}$ showed a 3-fold increase in the incidence of cerebral palsy with a therapy schedule beginning early and of short dura- tion ( 1 to 3 days) in a multicentric study. These results showed that neurological effects may also occur following therapy schedules of short duration.

Based on the literature, the use of corticosteroids in preterm infants who are dependent on mechanical ventilation and are at risk for development of BPD in the neonatal period is not advised. ${ }^{54,55}$

In spite of these recommendations, there are still doubts regarding the long-term adverse effects of corticosteroid use due to the fact that these investigations are heterogeneous. In addition, there is an unsolved contradiction in that the neurological effects have not been observed during longterm follow-up when the corticosteroids were introduced between 10 to 14 days of life. These results raise doubts as to the inevitability of long-term neurological effects.

Although dexamethasone, the most commonly used corticosteroid in major studies, produces these side effects, other corticosteroids such as beclomethasone may not. ${ }^{56}$ This issue requires further study.

Some neonatal units, including many in Brazil, continue to use dexamethasone with restricted indications ${ }^{57}$ despite existing recommendations. Therefore, new studies to analyze the neurological evolution of the newborns that received corticosteroids in the neonatal period, mainly between 10 and 14 days of life, is necessary.

The results of this study do not favor the use of corticosteroids in preterm newborns dependent on mechanical ventilation between 10 and 14 days of life because there was no evidence of favorable effects upon the respiratory evolution of these newborns, although a tendency for lower mortality was detected; on the other hand, unfavorable effects upon growth were detected.

Moreover, recent investigations regarding the pathophysiological mechanisms involved in "new" BPD emphasize the great importance of perinatal development and suggest beginning the use of mechanical ventilation earlier and continuing for a period longer than 7 days. Therefore, beginning treatment with corticosteroids between 10 and 14 days of life could be too late for prevention of BPD, in addition to increasing the risk of unfavorable effects on growth and adverse effects.

\section{RESUMO}

MATALOUN MMGB e col. Efeitos de corticosteróides em recém-nascidos de muito baixo peso, dependentes de ventilação mecânica. CLINICS 60(2):113-120, 2005.

Devido às suas ações anti-inflamatórias, os corticos- teróides têm sido utilizados para prevenção de displasia broncopulmonar, sendo descrita, uma redução da incidência desta patologia. No entanto, efeitos adversos a curto e a longo prazo têm sido detectados, em recém-nascidos prétermo. 
OBJETIVO: Analisar os efeitos sobre a incidência de displasia broncopulmonar, duração de ventilação mecânica e de internação, mortalidade, crescimento, além dos efeitos adversos dos corticosteróides, administrados entre 10-14 dias de vida, em recém-nascidos de muito baixo peso, dependentes de ventilação mecânica.

MÉTODOS: Realizou-se estudo de coorte, incluindose todos os recém-nascidos com peso de nascimento $<1500$ gramas dependentes de ventilação mecânica, entre 10-14 dias de vida. Foram divididos em: Grupo I - receberam dexametasona (16) e Grupo II - não receberam dexametasona (22). Administrou-se dexametasona, a partir do $10^{\circ}$ dia de vida, dias 1 a $3-0,3 \mathrm{mg} / \mathrm{kg} / \mathrm{d}$, dias 4 a $6-0,2$ $\mathrm{mg} / \mathrm{kg} / \mathrm{d}$, dias 7 a $9-0,1 \mathrm{mg} / \mathrm{kg} / \mathrm{d}$. Analisou-se o desenvolvimento de displasia broncopulmonar (dependência de oxigênio aos 28 dias de vida), efeitos sobre a evolução respi- ratória e sobre o padrão de crescimento, além da ocorrência de efeitos adversos.

RESULTADOS: A incidência de displasia broncopulmonar não diferiu entre os grupos (GI - 62,5\%; GII $22,7 \% ; p=0,07)$. Detectou-se desaceleração do crescimento no GI em relação ao GII(D P $=47 \mathrm{~g} / \mathrm{semana}$, GI e 85,5g/ semana, GII; $p=0,06$; D PC $-0,75 \mathrm{~cm} / \mathrm{semana}$ GI e $1 \mathrm{~cm} /$ semana, no GII; $p=0,05$ ).

CONCLUSÃO: O uso de corticosteróides, em recém-nascidos pré-termo, entre 10 - 14 dias de vida não reduziu incidência de displasia broncopulmonar e causou uma desaceleração do crescimento.

UNITERMOS: Corticosteróides. Recém-nascido prematuro. Displasia broncopulmonar.

\section{REFERENCES}

1. Hack M, Fanaroff A. Outcomes of children of extremely low birthweight and 1. Hack M, Fanaroff A. Outcomes of children of extremely low birthweight and gestational age in the 1990's. Early Human Devel 1999;53(3):193-218.

2. Korhonen P, Tammela O, Koivisto A-M, Laippala P, Ikonen S. Frequency and risk factors in bronchopulmonary dysplasia in a cohort of very low birth weight infants. Early Human Devel $1999 ; 54(3): 245-58$.

3. Kraybill E, Bose C, D‘Ercole A. Chronic lung disease in infants with very low birth weight. A population based study. Am J Dis Child 1987;141:784-8.

4. Yip Y, Tan K. Bronchopulmonary dysplasia in very low birth weight. J Pediatr Child Health 1991;27:34-8.

5. Brozanski BS, Jones JG, Gilmour CH, Balsan MJ, Vazquez RL, Israel BA et al. Effect of pulse dexamethasone therapy on the incidence and severity of chronic lung disease in the very low birth weight infant. J Pediatr 1995;126:769-76.

6. Rastogi A, Akintorin SM, Bez ML, Morales P, Pildes RS. A controlled trial of dexamethasone to prevent bronchopulmonary dysplasia in surfactant-treated infants. Pediatrics 1996;98:204-10.

7. Halliday HL. Clinical trials of postnatal Ccorticosteroids: inhaled and systemic. Biol Neonate 1999;76(suppl 10):29-40.

8. Tapia JL, Ramirez R, Cifuentes J, Fabres J, Hübner E, Bancalari A et al. The effect of early dexamethasone administration on bronchopulmonary dysplasia in preterm infants with respiratory syndrome. J Pediatr 1998;132:48-52.

9. Halliday HL, Ehrenkranz RA, Doyle LW. Early postnatal $(<96$ hours) corticosteroids for preventing chronic lung disease in preterm infants. In the Cochrane Library, issue 4, 2004, Oxford: Update Software.
10. Avery GB, Fletcher AB, Kaplan M, Brudno S. Controlled trial of dexamethasone in respirator-dependent infants with bronchopulmonary dysplasia. Pediatrics 1985;75:106-11.

11. Gladstone IM, Ehrenkranz RA, Jacobs HC. Pulmonary function tests and fluid balance in neonates with chronic lung disease during dexamethasone treatment. Pediatrics 1989;84:1072-6.

12. Cummings JJ, D'Eugenio DB, Grossi SJ. A controlled trial of dexamethasone in preterm infants at high risk for bronchopulmonary dysplasia. N Engl J Med 1989;320:150510 .

13. Collaborative Dexamethasone Trial Group. Dexamethasone therapy in neonatal chronic lung disease: an international placebo-controlled trial. Pediatrics 1991;88:421-7.

14. Ohlsson A, Calvert AS, Hosking M, Shennanm AT. Randomized controlled trial of dexamethasone treatment in very-low-birthweight infants with ventilator-dependent chronic lung disease. Acta Paediatr 1992;81:751-6.

15. Ferrara TB, Couser RJ, Hoesktra RE. Side effects and long-term follow-up of corticosteroid therapy in very low birthweight infants with bronchopulmonary dysplasia. J Perinatol 1990;10:137- 42 .

16. Yeh TF, Torre JA, Rastogi A, Anyebuno MA, Pildes R. Early postnatal dexamethasone therapy in premature infants with severe respiratory distress syndrome. A double-blind, controlled study. J Pediatr 1990;117:273-82.

17. Werner JC, Sicard RE, Hansen TR, Solomon E, Cowett RM, Oh W. Untoward cardiac effects of dexamethasone therapy for bronchopulmonary dysplasia. Pediatr Res 1991;29:249A.

18. Bedard MP. Intestinal perforation associated with dexamethasone therapy in the neonate. Pediatr Res 1988;23:255A. 
19. Aszlalos EV, Ohlssom A., Shennam AT, Smith J. Is dexamethasone treatment a risk factor for retinopathy of prematurity? Results of a case control study. Pediatr Res 1991;29:201A

20. Ng PC, Blackburn ME, Brownlec KG . Adrenal response in very low birthweight babies after dexamethasone treatment for bronchopulmonary dysplasia. Arch Dis Child 1989;64:172126.

21. Boulet L-P, Giguère M-C, Milot J., Brown J. Effects of long-term use of high-dose inhaled steroids on bone density and calcium metabolism. J Allergy Clin Immunol 199494:796-803

22. Lin YJ, Yeh TF, Lin HC, Yu CY. Effects of early postnata dexamethasone therapy on calcium homeostasis and bone growth in preterm infants with respiratory distress syndrome. Acta Paediatr 1998; 87:1061-5.

23. Papile LA, Tyson JE, Stoll BJ, Wright LL, Donovan EF, Bauer C et al. A multicenter trial of two dexamethasone regimens in ventilator-dependent premature infants. $\mathrm{N}$ Engl J Med 1998;338:1112-8.

24. Mataloun MMGB, Gibelli MAC, Kato AV, Vaz FAC, Leone CR. Use of corticosteroids and the outcome of infants with bronchopulmonary dysplasia. Rev Hosp Clin Fac Med S Paulo 1999;54(6):175-80.

25. Stoll BJ, Temprosa M, Tyson JE, Papile LA, Wright LL, Bauer CR et al. Dexamethasone therapy increases infection in very low birth weight infants. Pediatrics 1999;104(5):E63.

26. Yeh TF, Lin YJ, Huang CC. Early dexamethasone therapy in preterm infants. A follow-up study. Pediatrics 1998;101:E7.

27. O'Shea M, Kothadia JM, Klinepeter KL. Randomized placebocontrolled trial of a 42-day tapering course of dexamethasone to reduce the duration of ventilator dependency in very low birth weight infants. Outcome study participants at 1 year adjusted age. Pediatrics 1999;104:15-21.

28. Ballard JL, Khoury JC, Wedig K, Wang L, Eilers-Walman BL, Lipp R. New Ballard score, expanded to include extremely premature infants. J Pediatr 1991;119(3):417-23.

29. Ramos JA. Avaliação do crescimento intra-uterino por medidas antropométricas do recém-nascido. São Paulo, 1983, 180p. Tese de Doutoramento- Faculdade de Medicina da Universidade de São Paulo.

30. Battaglia F.C., Lubchenco L.O. A practical classification of newborn infants by weight and gestational age. J Pediatr 1967,71:15961.

31. Bancalari E., Abdenour G.E., Feller R. Bronchopulmonary dysplasia: clinical presentation. J Pediatr 1979;95:819-23

32. Jobe AH, Bancalari E. Bronchopulmonary dysplasia. Am J Respir Crit Care Med 2001;163(7):1723-9.

33. Pields RS. Neonatal hyperglycemia. J Pediatr 1986;109(5):905-7.

34. Tan KL. Blood pressure in very low birth weight infants in the first 70 days postpartum. J Pediatr 1988;112:266-70.

35. Bell MJ, Tennberg JL, Feigin RD, Keating JP, Marshall R, Barton $\mathrm{L}$ et al. Neonatal necrotizing enterocolitis: therapeutic decisions based on clinical staging. Ann Surg 1978;187(1):1-7.
36. Papile L, Burstein J, Burstein R, Koffler H. Incidence and evolution of subependymal and intraventricular hemorrhage. A study of infants with birth weight less than 1500 grams. J Pediatr 1978:92:529-34

37. Tyson JE. Immediate care of the newborn infant. In: Sinclair JC, Bracken MB. Effective care of the newborn infant. Oxford, Oxford University Press 1992;21-39.

38. An international classification of retinopathy of prematurity. Pediatrics 1984;74:127-33.

39. Jantz MA, Sahn SA. Corticosteroids in acute respíratory failure. Am J Respir Crit Care Med 1999;160:1079-100.

40. Groneck P, Speer CP. Inflammatory mediators and bronchopulmonary dysplasia. Arch Dis Child 1995;73:F1-3.

41. Crapo JD. Morphologic changes in pulmonary oxygen toxicity. Am Rev Physiol 1986;48:721-31.

42. Jobe AH, Ikegami M. Lung development and function in preterm infants in the surfactant treatment era. Annu Rev Physiol $2000 ; 62: 825-46$

43. Coalson JJ, Vicki TW, Siler Khodr T, Yoder BA. Neonatal chronic lung disease in extremely immature baboons. Am J Respir Crit Care Med 1999;160:1333-46.

44. Albertine KH, Jones GP, Starcher BC, Bohnsack JF, Davis PL, Cho $\mathrm{S}-\mathrm{C}$ et al. Chronic lung injury in preterm lambs. Disordered respiratory tract development. Am J Respir Crit Care Med 1999;159:945-58.

45. Bancalari E, Gonzalez A . Clinical course and lung function abnormalities during development of neonatal chronic lung disease. In Bland R, Coalson JJ, editor. Chronic Lung Disease in Early Infancy. Lung Biology in Health and Disease. New York, Basel, Marcel Dekker, 2002. vol 137, p 41-62.

46. Garland JS, Alex CP, Pauly TH, Whitehead VL, Brand J, Winston JF et al. A three-day course of dexamethasone therapy to prevent chronic lung disease in ventilated neonates: a randomized trial. Pediatrics 1999;104:91-9.

47. Sinkin RA, Dweck HS, Horgan, MJ Gallaher KJ, Cox C, Moriscalco WM et al. Early dexamethasone-attempting to prevent chronic disease. Pediatrics 2000;105:542-8.

48. Stark AR, Carlo W, Bauer C, Donovan E, Papile L, Shankaran S et al. NICHD Neonatal Research Network. Complications of early steroid therapy in a randomized controlled trial. Pediatrics 1999;104:738-40.

49. Bhuta T, Ohlsson A. Systematic review and meta-analysis of early postnatal dexamethasone for prevention of chronic lung disease. Arch Dis Child Fetal Neonatal; ed 1998;79:F26-F33.

50. Brozanski BS, Jones JG, Gilmore CH. Effect of pulse dexamethasone therapy on the incidence and severity of chronic lung disease in very low birth weight. J Pediatr 1995;126:76976.

51. Kothadia JM, O'Shea TM, Roberts D, Auringer ST, Weaver RG, Dillard RG. Randomized placebo-controlled trial of a 42-day tapering course of dexamethasone to reduce the duration of ventilator dependency in very low birth weight infants. Pediatrics 1999; 104:22-7. 
52. Halliday HL, Ehrenkranz RA, Doyle LW. Moderately early (7-14 days) postnatal corticosteroids for preventing chronic lung disease in preterm infants. In The Cochrane Library, issue 4, 2004, Oxford: Update Software.

53. Halliday HL, Ehrenkranz RA, Doyle LW. Delayed postnatal corticosteroids for preventing chronic lung disease in preterm infants. In The Cochrane Library, issue 4, 2004, Oxford: Update Software.

54. Shinwell ES, Karplus M, Zmora E, Reich D, Rothschild A, Blazer $\mathrm{S}$ et al. Failure of early postnatal dexamethasone to prevent chronic lung disease in infants with respiratory distress syndrome. Arch Dis Child 1996;74:33-37.
55. American Academy of Pediatrics and Canadian Paediatric Society Postnatal corticosteroids to treat or prevent chronic lung disease in preterm infants. Committee on Fetus and Newborn. Pediatrics 2002;109(2):330-8.

56. Jobe AH. Postnatal corticosteroids for preterm infants- Do what we say, not what we do. N Eng J Med 2004;350(13):1349-51.

57. Truffert P, Empana J-P, Bréart G, Saugstad OD, Goelz R, Halliday HL et al. Treatment strategies for bronchopulmonary dysplasia with postnatal corticosteroids in Europe: the EURAIL survey. Acta Paediatr 2003;92:948-51. 